\title{
Sparkling Reality: Can Foreign Direct Investments Alone Revive the Akwatia Diamond Mine and Diamond Exports in Ghana?-A Cointegration Analysis
}

\author{
Ze Tian', Enoch Kwaw-Nimeson'2, Grace Opoku Onyinah ${ }^{3}$ \\ ${ }^{1}$ Low Carbon Economy Research Institute, Hohai University, Changzhou Campus, Changzhou, China \\ ${ }^{2}$ Department of Business Administration, Business School, Hohai University, Jiangning Campus, Nanjing, China \\ ${ }^{3}$ Business Department, Nueta Hidatsa Sahnish College, New Town, North Dokota, USA \\ Email: tianze21@126.com, enochnimeson@protonmail.com, graceopokuonyinah@gmail.com
}

How to cite this paper: Tian, Z., Kwaw-Nimeson, E. and Onyinah, G.O. (2019) Sparkling Reality: Can Foreign Direct Investments Alone Revive the Akwatia Diamond Mine and Diamond Exports in Ghana?-A Cointegration Analysis. Open Journal of Business and Management, 7, 1846-1861.

https://doi.org/10.4236/ojbm.2019.74127

Received: August 29, 2019

Accepted: September 27, 2019

Published: September 30, 2019

Copyright $\odot 2019$ by author(s) and Scientific Research Publishing Inc. This work is licensed under the Creative Commons Attribution International License (CC BY 4.0).

http://creativecommons.org/licenses/by/4.0/ (c) (i) Open Access

\begin{abstract}
The Akwatia Diamond Mine has been responsible for most of the diamond-related activities in Ghana. This study analyses the factors responsible for the recent lack of investments inflows into the Mine and also assesses diamond export performance in Ghana using the annual time series data from 1987 to 2018. The Gravity Model, a well-known model for trade flow analyses is employed into the study to assess the relationship between diamond exports and foreign direct investments as well measure its impact on gross domestic product, diamond price, real effective exchange rate and inflation rate. The study found a positive but insignificant impact of foreign direct investments on diamond export over the period under study in the long run and also reports little or no direct impact on diamond exports in the short run. The study recommends that the Government of Ghana should introduce punitive laws and regulations to guide the next Akwatia Diamond Mine divestiture to avoid a repeat of the past divestiture failures. Additionally, the study recommends that the Government of Ghana should reconsider lifting the ban on artisanal diamond mining and rather formulate and adopt policies to manage and supervise their activities to boost diamond production, exports and revenue.
\end{abstract}

\section{Keywords}

Diamond, Diamond Sector, Akwatia Diamond Mine, Cointegration, Foreign

Direct Investments 


\section{Introduction}

Total revenue from diamond exporting countries was US\$127.9 billion in 2018, of which Ghana's exports amounted to $\$ 2.1$ million, representing a $0.002 \%$ of global output ${ }^{1}$. This output value is an added evidence of the fast decline of the diamond sector of Ghana for the greater part of two decades. The rather unfortunate circumstance that the sector finds itself can be traced back to the closure of the Akwatia Diamond Mine in 2007 in part as a result of lack of investment and mismanagement of the mine.

The Akwatia Diamond Mine is situated in the Birim Diamond Field in the Eastern Region of Ghana ran by the erstwhile Ghana Consolidated Diamond Limited (GCDL) and has produced more than 100 million carats of diamond since it first started operations [1]. At the moment, the diamond field has close to 20 million carats of unmined diamond deposits covering an area of 240 kilometers square. However, the Mine which had been under divestiture since 1993 [2] was briefly saved by the funds provided by the Structural Adjustment Programs (SAPs) introduced in Sub-Saharan African (SSA) developing and underdeveloped countries by the World Bank in 1983. Under the SAPs, Ghana greatly benefitted from the program which saw massive foreign investment inflows into the mining sector, leading to increased production, exports, revenue and employment. The funds from the SAPs strengthened the Precious Minerals Marketing Company (PMMC) $\operatorname{Ltd}^{2}$., the governmental body who at the time was responsible for all diamond sector and diamond-related activities in Ghana.

\section{History of the Akwatia Diamond Mine and Performance of the Diamond Sector Under the SAP (1987-2018)}

The diamond sector of Ghana was the number one mineral produced and exported in Ghana, being the biggest contributor to foreign exchange earnings to gross domestic product (GDP) in Ghana from the 1920s until the SAPs [3]. In 2005, the Akwatia Mine was in a "maintenance-phase", nearing closer to another collapse ${ }^{3}$ until 2007 when it was finally closed to operations, rendering about 800 workers redundant after the Divestiture Implementation Committee (DIC) revoked the license of Sapper and Associates, who at the time had won the te1nder to operate the Mine. Nonetheless, before the closure of the Mine, the United Nations (UN) in 2006 banned Ghana from exporting diamonds, as there was a doubt that Ghana was dealing with conflict diamonds. The Mine, however, was reopened in August, 2011 after a Ghanaian-owned company, the Great Consoli${ }^{1}$ Report can be assessed at http://www.worldstopexports.com/diamond-exports-country/.

${ }^{2}$ The Precious Minerals Marketing Company (PMMC) Ltd. was established in 1963 as Ghana Diamond Marketing Board charged with the responsibility for the purchase and marketing of Ghana's diamonds. In 1965, by Legislative Instrument (LI) 401, the Company was incorporated as a State Owned Enterprise (SOE).

${ }^{3}$ The Mine was reported to be on the verge of collapse owing to the failure of the company that won the original divestiture tender to inject the needed $\$ 34$ million to revive the sector as stated in the tender documents. Report can be assessed at

https://www.ghanaweb.com/GhanaHomePage/business/Akwatia-Diamond-Mine-Nearing-Collapse$\underline{83058 .}$ 
dated Diamond Company Ltd. (GCDCL) won the tender to operate the Mine 4 In a call to government in December 2017, the Legislature of Ghana's Parliament advocated for GCDCL's license revocation for failing to honor its contractual obligations, six years after the said contract was signed between the two parties ${ }^{5}$. According to the divestiture agreement between government and GCDCL, GCDCL promised among other things, to invest $\$ 100$ million in a five-year period, with a projected production of one million carats of diamond per year within the period, creating 2500 direct and 50,000 indirect jobs.

In March 2019, DIC finally abrogated its agreement with GCDCL. The reasons assigned to the abrogation were the persistent failure of the company to settle its debts, arising from non-payment of the balance ${ }^{6}$ due from the divestiture of the assets of GCDL to GCDCL. This new development in the sector currently leaves the Akwatia Diamond Mine and the people of Akwatia hanging in the balance as to when and from where the next divestiture is going to come from and as to whether it would be sustainable enough to provide the necessary foundation to commence operational and commercial activities at the mine, provide jobs for the local people as well as bring an economic facelift to the Akwatia township.

The significance of this study is to point out among others; the extent to which the investments that came as a result of the SAPs and the recent divestitures benefitted the diamond sector in the short term but cast a shadow on the long term productivity sustainability of the sector. The study also seek to establish the probable profitability between diamond sector investments and diamond exports for the period under study and also the underlying factors responsible for the failure of the previous divestitures by Sapper and Associates and GCDCL. The paper also attempts to ascertain the factors that would be necessary for a successful divestiture, sustainability and profitability of the Akwatia Diamond Mine.

Figure 1 shows a graphical representation of the performance of the Diamond Sector in Ghana, during the period of the SAP and the period after the SAP. The most productive year recorded for diamond exportation in Ghana was in 2005 when a total of 1013616 carats of diamond were exported. The sector began to experience a sharp decline in production from 2008 were exports fell by $39.56 \%$ from the figure recorded for 2005. Exports hit a record low in 2018 with only 62786 carats exported.

\section{Literature Review}

Capital investment is targeted at sectors and industries that promise the highest ${ }^{4}$ The GCDCL took over the Mines from the then governed-owned Ghana Consolidated Diamonds (GCD). Report can be assessed at https://www.rough-polished.com/en/exclusive/101955.html.

${ }^{5}$ Report can be assessed at https://www.graphic.com.gh/news/politics/withdraw-licence-of-great-consolidated-diamond-ghanalimited-mps.html.

${ }^{6}$ At the time of the contract abrogation, GCDCL owed DIC US $\$ 18,844,014.45$. Report can be assessed at

https://www.businessghana.com/site/news/General/186719/DIC\%20abrogates\%20agreement\%20wit h\%20Akwatia\%20Mine. 


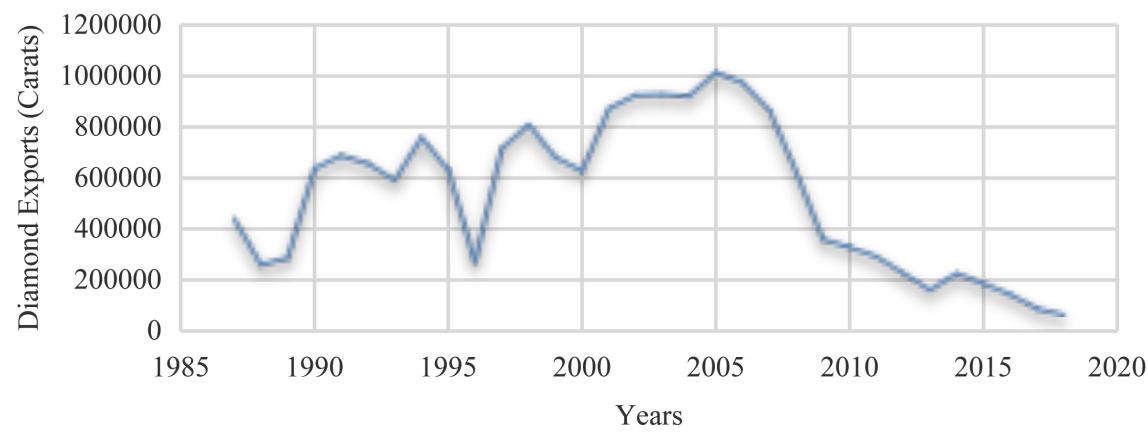

Figure 1. Performance of diamond sector (1987-2018). Source: Authors' Construct (Statistics from Minerals Commission of Ghana)

returns [4]. The mining sector ${ }^{7}$ of Ghana since the introduction of the Economic Recovery Programs (ERP) in 1983 SAPs has been positioned to attract FDI inflows. Statistics show that the largest portion of FDI goes to the mining ${ }^{8}$ and oil industries in Africa [5]. In Ghana, a plethora of related socio-economic research into the mining sector has been conducted, with various conclusions drawn. We cite a few of such researches below that are pertinent to this study.

- Generally, FDI has been seen to have a positive relationship with production and exports [6]-[11] with a further stress on the nature of the relationship between FDI and exports; which might be seen to be substitutional [12] [13] [14] or complementary [15] [16] [17] [18]. There also seem to exist a negative correlation between FDI and exports among developed countries [19] [20].

- The role FDI has played in shaping the economies of developing countries cannot be overstated. Thus, influencing trade patterns in China [21] [22] in Poland; Hungary and the Czech Republic [23], in Hungary and Slovenia [24] as well as in 8 Latin American countries [25].

- FDI's impact on economic growth and development has been widely investigated as well [26] [27] [28]. For instance, is FDI dependent on other factors and differs from country to country? [29], or even on microeconomic economic conditions and the business environment of the host country? [30] [31] [32] [33] [34] goes as far as crediting the level of education or skills of the workforce of the host country as a factor for FDI impact on economic growth whereas others [35] [36] are of the view that FDI is impactful only if the host country is macro-economically stable.

- It is no secret that depreciation of the host country's currency might drive up future investment inflows [37] [38] but also worthy to not that exchange rate instability generally has had a negative impact on FDI in Ghana [39] [40].

- Based on varying expectations, FDI is projected to have a positive effect on ${ }^{7}$ According to the Chief Executive Officer to the Ghana Chamber of Mines, Mr. Sulemanu Koney, FDI inflows into Ghana's mining sector from 1983 to 2016 was $\$ 16$ billion. Report can be assessed at https://www.modernghana.com/news/742051/ghanas-mining-attracts-investment-of-us16-billion.ht $\underline{\mathrm{ml}}$.

${ }^{8}$ More than $90 \%$ of all mining sector-related FDIs inflows has been to the gold sub-sector from the period of the SAPs until now. 
GDP and GDP growth rate [6] [41] whiles it has also been widely reported to have a negative relationship with international price of commodities [42] and inflation rate [43] [44].

- The history of commodities exports in Africa is such that not much value is added to the exported raw materials and this affects foreign exchange earnings. Based on the statistics from the Ghana Chamber of Mines ${ }^{9}$ and the Kimberley Process ${ }^{10}$, close to $80 \%$ of all diamonds mined are exported in their raw forms whereas the rest are processed locally to make jewelry or for other industrial purposes. Figure 1 presents the graph of the performance of the diamond sector for the period under study.

\section{Methodology and Materials}

\subsection{Data and Data Sources}

Annual time series data from 1987 to 2018 obtained from various institutions are used for the analysis in this study. The econometric software EVIEWS 10 was used for the multivariate computation and analysis. Table 1 presents data sources and units used in the study.

\subsection{Model Specification}

The framework of analysis is centered on the gravity model of international trade. The gravity model measures the relationship between a trade-related response variable and selected explanatory variables such as prices, GDP, inflation, exchange rate and income [45].

Based on the gravity model, the basic model of export trade flows is stated as follows:

Table 1. Data and data sources.

\begin{tabular}{ccc}
\hline \multicolumn{1}{c}{ Variable } & Source & Unit \\
\hline 1) Diamond Exports from Ghana (DExZ) & $\begin{array}{c}\text { Minerals Commission of Ghana }{ }^{11} \text {, Ghana } \\
\text { Chamber of Mines, Kimberley Process. }\end{array}$ & Carats \\
2) Foreign Direct Investment (FDI) & Minerals Commission of Ghana, Ghana & US \$ \\
3) Gross Domestic Product (GDP) & Chamber of Mines. & $\%$ \\
4) Diamond Prices (DPx) & World Bank & US \$ \\
5) Real Effective Exchange Rate (REER) & Kimerals Commission of Ghana, & $\%$ \\
6) Inflation Rate (INFRATE) & World Bank & $\%$
\end{tabular}

Source: Authors' Construct.

${ }^{9}$ The Ghana Chamber of Mines is a subsidiary of the Ministry of Lands and Natural Resources that administers the interest of all stakeholder in the sector-mine exploration companies, production companies, mine support service companies as well as mineral export entities.

${ }^{10}$ The Kimberley Process is the UN's international certification scheme that is responsible for the diamond-producing countries production and trade of rough diamonds.

${ }^{11}$ Most of the diamond export, FDI and Diamond Prices data was collected in person by the corresponding author, as especially the data from 2013 to 2018 are not available on their official website. 


$$
X_{i j t}=\beta_{0} Y_{i t}^{\beta_{1}} Y_{j t}^{\beta_{2}} \prod_{m=1}^{M}\left(Z_{i j t}^{m}\right)^{\beta_{m}} \varepsilon_{i j t}
$$

where, $X_{i j t}$ is the magnitude of diamond export between Ghana and trading partners ${ }^{12}, Y_{i t} Y_{j t}$ are the revenues of the countries, $\prod_{m=1}^{M}\left(Z_{i j t}^{m}\right)^{\beta_{m}}$ is the set of indicators, having both positive and negative impact on trade flows. Trade flows in this instance include diamond exports (DEx), foreign direct investment (FDI), gross domestic product (GDP), internal price of diamond (DPx), real effective exchange rate (REER), and inflation rate (INFRATE). $\varepsilon_{i j t}$ is the random error term.

Reference [21] explains that:

$$
\beta_{0}^{*}=\beta_{0} Y_{j t}^{\beta_{2}}
$$

The gravity model of export trade flows is therefore stated as follows:

$$
X_{i j t}=\beta_{0}^{*} Y_{i t}^{\beta_{1}} \prod_{m=1}^{M}\left(Z_{i j t}^{m}\right)^{\beta_{m}} \varepsilon_{i j t}
$$

The general equation is usually estimated in a log linear form as:

$$
\ln X_{j t}=\beta_{0}^{*}+\beta_{1} \ln Y_{i t}+\sum_{m=1}^{M} \beta_{m} \ln Z_{i j}^{m}+\varepsilon_{t}
$$

The method of adding additional variables in the gravity model of international trade has been used in a number of studies [21] [46] [47]. In this study, DEx is identified as the response variable whiles FDI, GDP, geographical distance ${ }^{13}, \mathrm{DPx}^{14}, \mathrm{REER}^{15}$ and INFRATE are employed as explanatory variables.

The distance variable is expected to have a negative relationship with diamond export and is stated as:

$$
\operatorname{DIST}=\sum_{j=1}^{j} w_{j} D_{i j}
$$

where,

$$
w_{i j}=\frac{Y_{j}}{Y_{w}}
$$

$Y_{j}=$ Country $j$ s GDP, $Y_{w}=$ World GDP and $D_{i j}=$ Direct distance between country $i$ and country $j$

Therefore this mathematical equation is thus derived to examine the factors that impact diamond exports:

$$
\begin{aligned}
\ln \mathrm{DEx}_{t}= & \beta_{1}+\beta_{2} \ln \mathrm{FDI}_{t}+\beta_{3} \ln \mathrm{DIST}+\beta_{4} \ln \mathrm{GDP}_{t}+\beta_{5} \ln \mathrm{DPx}_{t} \\
& +\beta_{6} \ln \mathrm{REER}_{t}+\beta_{7} \ln \mathrm{INFRATE}_{t}+\varepsilon_{t}
\end{aligned}
$$

where the $\beta$ s are the regression parameters to be estimated and the variables as they have been previously defined. $\varepsilon_{t}$ is assumed to be the error term.

\footnotetext{
${ }^{12}$ Ghana's diamond trade partners historically include Belgium, The Netherlands and the USA.

${ }^{13}$ The distance variable is calculated by the weighted average distance from Ghana to all major diamond export destinations, and the weight is the share of country js GDP as a percentage of the world's total GDP.

${ }^{14}$ The price of diamond is decided based on the four Cs of diamonds-cut, clarity, color and carat. For the purpose of this study, we adopted the internal diamond prices of Ghana for the period under study.

${ }^{15}$ The value of the United States' dollar in terms of the Ghanaian Cedi is used as a proxy for the international exchange rate.
} 


\subsection{Unit Root Tests}

To illustrate the use of the Augmented Dickey-Fuller tests, consider first an $\mathrm{Au}$ toregressive (AR) (1) model:

$$
y_{t}=\mu+\rho y_{t-1}+\varepsilon_{t}
$$

where $\mu$ and $\rho$ are parameters and $\varepsilon_{t}$ is assumed to be white noise. $y$ is a stationary series if $-1<\rho<1$, and $y$ is a nonstationary series if $\rho=1$. If the absolute value of $\rho$ is greater than one, the series becomes explosive. Therefore, we test whether the absolute value of $\rho$ is strictly less than 1 by making the assumption that the null hypothesis is: $\rho=1$ and then test it against the alternative hypothesis: $\rho<1$.

Subtracting $y_{t-1}$ from both sides of Equation (8)

$$
\Delta y_{t}=\mu+\gamma y_{t-1}+\varepsilon_{t}
$$

where $\gamma=(\rho-1)$ and the null and alternative hypotheses are $H_{0}: \gamma=0$ and an alternate hypothesis of

$$
H_{0}: \gamma<0
$$

The ADF approach controls for higher-order correlation by adding lagged difference terms of the dependent variable $y$ to the right-hand side of the regression:

$$
\Delta y_{t}=\mu+\gamma y_{t-1}+\Sigma \Delta y_{t-1}+\varepsilon_{t}
$$

This augmented specification is then used to test the following hypothesis:

$$
H_{0}: \gamma=0 \text { and an alternate hypothesis of } H_{1}: \gamma<0
$$

\section{Results and Discussions}

\subsection{Analysis of the Descriptive and Correlation Statistics}

The averages for diamonds exports and yearly FDI for the period under study are 538,593 carats and $\$ 5.1$ million respectively. Also values for real exchange were $4.69 \mathrm{GHS}^{16}(\max )$ and $0.015 \mathrm{GHS}(\min )$; and $59.5 \%(\max )$ and $8.7 \%(\min )$ were recorded for the rate of inflation for the period under study.

Table 2 summarizes the descriptive statistics obtained whiles Table 3 presents the correlation matrix of the model. As expected, the response variable exhibits a fairly strong relationship with the explanatory variables.

\subsection{Results of Analysis of the Time-Series Properties of the Variables}

The ADF tests results show that all the variables to be insignificant at all levels but significant at first difference. Table 4 presents the results of the ADF test and first difference results of the variables. The results also show that all the variables fall beyond their respective p-values, indicating a rejection of the null hypothesis of a unit root in favor of the alternative hypothesis of no unit root. The implication of these results is that all the variables entering into the Error Correction Model (ECM) are integrated of order 1.

${ }^{16}$ GHS-Ghanaian Cedis (local currency), in terms of trading (foreign) currency (US Dollar). 
Table 2. Descriptive statistics.

\begin{tabular}{ccccccc}
\hline Variable & Mean & Median & S.D & Maximum & Minimum & Kurtosis \\
\hline DEx & 538592.7 & 624871.5 & 296855.3 & 1013616 & 62786 & 1.632910 \\
FDI & 5092249 & 5157463 & 2616624 & 9588444 & 225789 & 2.011935 \\
GDP & 5.396875 & 4.800000 & 2.313283 & 14.00000 & 2.200000 & 7.258947 \\
DPx & 31.35125 & 29.32000 & 8.433412 & 56.04000 & 20.20000 & 4.675403 \\
REER & 1.154781 & 0.829500 & 1.371977 & 4.690000 & 0.015000 & 3.852173 \\
INFRATE & 20.95000 & 16.80000 & 12.05918 & 59.50000 & 8.700000 & 4.738071 \\
Observation & 32 & 32 & 32 & 32 & 32 & 32 \\
\hline
\end{tabular}

Source: Authors' Computation.

Table 3. Correlation statistics.

\begin{tabular}{|c|c|c|c|c|c|c|}
\hline Correlation & DEx & FDI & GDP & $\mathrm{DPx}$ & REER & INFRATE \\
\hline DEx & 1.000000 & & & & & \\
\hline FDI & 0.731040 & 1.000000 & & & & \\
\hline GDP & -0.158474 & 0.072525 & 1.000000 & & & \\
\hline $\mathrm{DPx}$ & -0.512525 & -0.365360 & 0.438818 & 1.000000 & & \\
\hline REER & -0.402260 & -0.451726 & 0.205720 & 0.503777 & 1.000000 & \\
\hline INFRATE & 0.212771 & 0.262046 & -0.439824 & -0.553409 & -0.576693 & 1.000000 \\
\hline
\end{tabular}

Source: Authors' Computation.

Table 4. Summary of ADF unit root tests on variables.

\begin{tabular}{|c|c|c|c|c|c|c|}
\hline Variable & ADF Stat. & C.V at $1 \%$ & C.V at $5 \%$ & C.V at $10 \%$ & P-Value & T.C \\
\hline $\operatorname{lnDEx}$ & -0.964937 & -2.641672 & -1.952066 & -1.610400 & 0.2917 & $\mathrm{I}(1)$ \\
\hline $\operatorname{lnFDI}$ & -1.052329 & -2.641672 & -1.952066 & -1.610400 & 0.2576 & I (1) \\
\hline $\ln G D P$ & -3.591700 & -2.641672 & -1.952066 & -1.610400 & 0.4460 & I (1) \\
\hline $\ln D P x$ & 0.080500 & -2.641672 & -1.952066 & -1.610400 & 0.7010 & I (1) \\
\hline lnREER & -1.865133 & -2.644302 & -1.952473 & -1.610211 & 0.0601 & I (1) \\
\hline lnINFRATE & -0.994658 & -2.641672 & -1.952066 & -1.610400 & 0.2799 & I (1) \\
\hline $\mathrm{D}(\ln \mathrm{DEx})$ & -5.482075 & -2.644302 & -1.952473 & -1.610211 & 0.0000 & $\mathrm{I}(0)$ \\
\hline $\mathrm{D}(\ln \mathrm{FDI})$ & -6.567363 & -2.644302 & -1.952473 & -1.610211 & 0.0000 & $\mathrm{I}(0)$ \\
\hline $\mathrm{D}(\ln \mathrm{GDP})$ & -6.735390 & -2.644302 & -1.952473 & -1.610211 & 0.0000 & I $(0)$ \\
\hline $\mathrm{D}(\ln \mathrm{DPx})$ & -5.494568 & -2.647120 & -1.952910 & -1.610011 & 0.0000 & I $(0)$ \\
\hline $\mathrm{D}(\operatorname{lnREER})$ & -2.388794 & -2.644302 & -1.952473 & -1.610211 & 0.0187 & $\mathrm{I}(0)$ \\
\hline $\mathrm{D}$ (InINFRATE) & -6.282966 & -2.644302 & -1.952473 & -1.610211 & 0.0000 & $\mathrm{I}(0)$ \\
\hline
\end{tabular}

Source: Authors' Construct.

\subsection{Results for Cointegration Analysis}

Having established the univariate properties of the variables, we went ahead to test to see if any long-run relationship existed among the variables. Hence, a Jo- 
hansen Cointegration test was performed to determine the cointegrating rank of the model and the number of common stochastic trends that exist among the variables. The results of the Johansen Cointegration test are presented in Table 5.

At most, there are at least three cointegrating vectors that can be established at a $5 \%$ significance level among the six variables indicated by both the Trace and Maximum Eigen value statistics. In order to have a full understanding of the extent of the relationship among the explanatory variables and the response variable, the long run model was assessed with the understanding of how the variables were assumed to have an effect on diamond exports based on the Engel-Granger methodology.

The estimated long-run model is given in Equation (12) below:

$$
\begin{aligned}
D(\ln \mathrm{DEx})= & 3.783+0.584 * D(\ln \mathrm{FDI})-0.339 * D(\ln \mathrm{GDP}) \\
& -0.915 * D(\ln \mathrm{DPx})-0.020 * D(\ln \mathrm{REER}) \\
& -0.331 * D(\ln \text { INFRATE })
\end{aligned}
$$

Table 6 presents the results of the estimated long-run equation with all five explanatory variables.

Table 5. Johansen cointegration test.

(a)

\begin{tabular}{ccccc}
\hline \multicolumn{4}{c}{ Unrestricted Cointegration Rank Test (Trace) } \\
\hline $\begin{array}{c}\text { Hypothesized } \\
\text { No. of CE(s) }\end{array}$ & Eigenvalue & $\begin{array}{c}\text { Trace } \\
\text { Statistics }\end{array}$ & $\begin{array}{c}0.05 \\
\text { Critical Value }\end{array}$ & Prob. $^{* *}$ \\
\hline None $^{*}$ & 0.952943 & 188.0257 & 95.75366 & 0.0000 \\
At most $1^{*}$ & 0.765178 & 99.39041 & 69.81889 & 0.0000 \\
At most 2 & 0.659923 & 57.37149 & 47.85613 & 0.0050 \\
At most 3 & 0.400737 & 26.09262 & 29.79707 & 0.1260 \\
At most 4 & 0.300231 & 11.24304 & 15.49471 & 0.1970 \\
At most 5 & 0.030220 & 0.889881 & 3.841466 & 0.3455 \\
\hline
\end{tabular}

Trace test indicates 3 cointegrating eqn(s) at the 0.05 level; ${ }^{*}$ denotes rejection of the hypothesis at the 0.05 level; ${ }^{* *}$ MacKinnon-Haug-Michelis (1999) p-values.

(b)

\begin{tabular}{ccccc}
\hline \multicolumn{4}{c}{ Unrestricted Cointegration Rank Test (Maximum Eigenvalue) } \\
\hline $\begin{array}{c}\text { Hypothesized } \\
\text { No. of CE(s) }\end{array}$ & Eigenvalue & $\begin{array}{c}\text { Max-Eigen } \\
\text { Statistic }\end{array}$ & $\begin{array}{c}0.05 \\
\text { Critical Value }\end{array}$ & Prob. $^{* *}$ \\
\hline None & 0.952943 & 88.63527 & 40.07757 & 0.0000 \\
At most $1^{*}$ & 0.765178 & 42.01891 & 33.87687 & 0.0043 \\
At most 2* & 0.659923 & 31.27887 & 27.58434 & 0.0160 \\
At most 3 & 0.400737 & 14.84958 & 21.13162 & 0.2996 \\
At most 4 & 0.300231 & 10.35316 & 14.26460 & 0.1898 \\
At most 5 & 0.030220 & 0.889881 & 3.841466 & 0.3455 \\
\hline
\end{tabular}

Max-eigenvalue test indicates 3 cointegrating eqn(s) at the 0.05 level; ${ }^{*}$ denotes rejection of the hypothesis at the 0.05 level; ${ }^{* *}$ MacKinnon-Haug-Michelis (1999) p-values. 
Table 6. Long-run cointegration equation.

\begin{tabular}{|c|c|c|c|c|}
\hline Variable & Coefficient & Std. Error & T-Stat & Prob. \\
\hline $\mathrm{C}$ & 3.783411 & 1.244919 & 3.039083 & 0.0054 \\
\hline $\operatorname{lnFDI}$ & 0.584338 & 0.121118 & 4.824552 & 0.0000 \\
\hline $\operatorname{lnGDP}$ & -0.339262 & 0.287037 & -1.181947 & 0.0050 \\
\hline $\operatorname{lnDPx}$ & -0.915141 & 0.493188 & -1.855563 & 0.1260 \\
\hline $\operatorname{lnREER}$ & -0.019576 & 0.068244 & -0.286849 & 0.1970 \\
\hline lnINFRATE & -0.331001 & 0.235971 & -1.402719 & 0.3455 \\
\hline R-squared & 0.641002 & \multicolumn{2}{|c|}{ Mean dependent var } & 5.638141 \\
\hline Adjusted R-squared & 0.571964 & \multicolumn{2}{|c|}{ S.D. dependent var } & 0.324283 \\
\hline S.E. of regression & 0.212160 & \multicolumn{2}{|c|}{ Akaike info criterion } & -0.095589 \\
\hline Sum squared resid & 1.170312 & \multicolumn{2}{|c|}{ Schwarz criterion } & 0.179237 \\
\hline Log likelihood & 7.529419 & \multicolumn{2}{|c|}{ Hannan-Quinn criter. } & -0.004492 \\
\hline F-statistic & 9.284751 & \multicolumn{2}{|c|}{ Durbin-Watson stat } & 1.035544 \\
\hline Prob(F-statistic) & 0.000036 & & & \\
\hline
\end{tabular}

Source: Authors' Construct.

The p-values indicate that in the long run, only FDI was significant at 5\% critical level and thus had a slight impact on diamond exports from Ghana. However, GDP, diamond price, real effective exchange rate as well as inflation rate were found to have no direct positive effect on diamond exports. The long-run static equation shows that 64.1 percent of the explanatory variables can be explained by the response variable. Moreover, the F-statistic of 9.28 is found to be significant as the F-test was used to determine whether the regression equation explained a significantly greater amount of diamond exports for the study period.

\subsection{Vector Error Correction Model (VECM) Analysis}

Having established the existence of a cointegration relationship among the variables, we proceed to estimate the short-run error correction model to assess equilibrium adjustments by using the disequilibrium estimates from the long-run model. The error correction term (ECT) is given as:

$$
\mathrm{ECT}_{t-1}=Y_{t-1}-\beta_{0}-\beta_{1} X_{t-1}-\beta_{2} X_{t-1}-\cdots-\beta_{n} X_{t-1}
$$

where the response variable is $Y_{t-1}, \beta_{0}$ is constant and $\beta_{1} X_{t-1}-\beta_{2} X_{t-1}-\cdots-\beta_{n} X_{t-1}$ are explanatory variables. The ECT cointegrating equation signifying a long-run relationship among the variables is therefore specified as:

$$
\begin{aligned}
\mathrm{ECT}_{t-1}= & 1.000 \ln \mathrm{DEx}_{t-1}-0.445 \ln \mathrm{FDI}_{t-1}+1.0285 \ln \mathrm{GDP}_{t-1}+3.692 \ln \mathrm{DPx}_{t-1} \\
& +0.002 \ln \mathrm{REER}_{t-1}+0.423 \ln \mathrm{INFRATE}_{t-1}-9.437
\end{aligned}
$$

Having specified the ECT, we estimated the short-run VECM equation as follows: 
$\mathrm{VECM}: \Delta y_{t}=\beta_{0}+\sum_{i=1}^{n} \beta_{1} \Delta y_{t-i}+\sum_{i=0}^{n} \beta_{2} \Delta x_{t-i}+\cdots+\sum_{i=n}^{n} \beta_{i} \Delta n_{t-1}+\varphi z_{t-1}+\mu_{t}(15)$

The results of the VECM is stated in Equation (16) as:

$$
\begin{aligned}
D\left(\ln _{\mathrm{GCEx}_{t}}\right)= & -0.079 \mathrm{ect}_{t-1}-0.139 * D\left(\ln \mathrm{DEx}_{t-1}\right)+0.129 * D\left(\ln \mathrm{FDI}_{t-1}\right) \\
& -0.177 * D\left(\ln \mathrm{GDP}_{t-1}\right)+0.626 * D\left(\ln \mathrm{DPx}_{t-1}\right) \\
& +0.948 * D\left(\ln \mathrm{REER}_{t-1}\right)-0.211 * D(\ln \mathrm{INFRATE})-0.101
\end{aligned}
$$

Table 7 presents the results of the error correction model. The first differences and the error term from the model based on the variables as shown in the table above are represented by $D$ and ect $_{t-1}$ respectively.

To interpret the results of the adjustment coefficients in Equation (16), it can be seen that the previous year's deviation from long-run equilibrium is corrected in the short-run at an adjustment speed of $7.92 \%$. Also, a percentage change in FDI is associated with a 0.12 percentage increase in diamond exports in the short run. Likewise, a percentage change in diamond prices and real effective exchange rate is also associated with a 0.63 and 0.95 percentage increase in diamond exports. However, a percentage change in GDP and inflation rate are associated with a 0.18 and 0.21 percentage decrease in diamond exports respectively. The results of the short-run estimation are consistent with UNCTAD (2017) ${ }^{17}$ which found that the total volume and value of diamonds exports in Botswana and Sierra Leone alone do not lead to an increase in GDP growth and poverty reduction. More so, all the explanatory variables used in the study do not significantly

\begin{tabular}{|c|c|c|c|c|}
\hline Variable & Coefficient & Std. Error & T-Statistics & Prob. \\
\hline $\mathrm{C}$ & -0.100556 & 0.052524 & -1.914476 & 0.0687 \\
\hline ECT Eqn & -0.079244 & 0.093238 & -0.849909 & 0.4045 \\
\hline $\mathrm{D}(\ln \mathrm{DEx}(-1))$ & -0.138921 & 0.186427 & -0.745179 & 0.4641 \\
\hline $\mathrm{D}(\ln \mathrm{FDI}(-1))$ & 0.128869 & 0.125545 & 1.026476 & 0.3158 \\
\hline $\mathrm{D}(\ln \mathrm{GDP}(-1))$ & -0.176790 & 0.196076 & -0.901641 & 0.3770 \\
\hline $\mathrm{D}(\ln \mathrm{DPx}(-1))$ & 0.626487 & 0.428820 & 1.460957 & 0.1582 \\
\hline $\mathrm{D}(\ln \operatorname{REER}(-1))$ & 0.947547 & 0.528620 & -1.272478 & 0.2165 \\
\hline $\mathrm{D}(\operatorname{lnINFRATE}(-1))$ & -0.211256 & 0.166020 & -1.402719 & 0.3455 \\
\hline R-squared & 0.330308 & \multicolumn{2}{|c|}{ Mean dependent var } & -0.020535 \\
\hline Adjusted R-squared & 0.117224 & \multicolumn{2}{|c|}{ S.D. dependent var } & 0.155633 \\
\hline S.E. of regression & 0.146226 & \multicolumn{2}{|c|}{ Akaike info criterion } & -0.784143 \\
\hline Sum squared resid & 0.470407 & \multicolumn{2}{|c|}{ Schwarz criterion } & -0.410490 \\
\hline Log likelihood & 19.76214 & \multicolumn{2}{|c|}{ Hannan-Quinn criter. } & -0.664608 \\
\hline F-statistic & 1.550129 & \multicolumn{2}{|c|}{ Durbin-Watson stat } & 2.198444 \\
\hline Prob(F-statistic) & 0.202661 & & & \\
\hline
\end{tabular}
influence diamond exports from Ghana in the short run.

Table 7. Long-run cointegration equation.

Source: Authors' Construct.

${ }^{17}$ Report can be assessed at https://unctad.org/en/PublicationsLibrary/suc2017d9_en.pdf. 


\section{Conclusions and Recommendations}

\subsection{Conclusions}

The results derived from the estimates used in the international trade export model presents some critically important policy implications for the Government of Ghana, the Ministry of Lands and Natural and allied stakeholders in the diamond sector of Ghana. Numerous research has shown the positive impact of FDI on Ghanaian exports both in the short and long run [2] [48] [49] but from the results and analysis of this study, we can conclude that FDI has a positive but insignificant impact on diamond exports in Ghana in the long run. We also report FDI to have little or no direct impact on diamond exports in the short run. Based on these results, we project that in the long run, an increase or decrease in FDI would bring about a proportionate impact on diamond exports in Ghana. We also report that the fundamental reason why both Sapper and Associates and GCDCL failed to deliver on their mandate was the failure of government of Ghana to conduct requisite background checks on them.

This was because prior to winning their respective tenders to take over the Akwatia Mine, none of them had previously been involved in any diamond activities. In the case of Sapper and Associates, in addition to not having any track record in the diamond industry, they failed to mobilize the required initial deposit of $\$ 3.2$ million, representing $10 \%$ of the agreed total investments. In the case of GCDCL, the company initially conducted feasibility studies on the mining field for three years and decided against using their own funds to undertake the mining project but rather scouting for partners outside of Ghana.

\subsection{Recommendations}

The diamond sector policy frameworks instituted in Ghana, right from the 1986 Minerals and Mining Law, PNDCL 153 to the present regulations ${ }^{18}$ have not been successfully implemented. It is the recommendation of this research that the Government of Ghana through the DIC should set out strict qualification criteria for prospective bidders to avoid the occurrence of the past takeover failures. The DIC must also conduct a thorough background check on bidders and set out stipulations to punish any divestiture company that falters on delivering on its mandate. Secondly, we recommend that the Ministry of Land and Natural Resources through the Minerals Commission lift the ban or introduce workable regulations on artisanal/small-scale diamond mining in the Akwatia area as it is no secret that it is the artisanal miners that have keep the sector afloat for most of the last decade. Thirdly, we recommend that maximum participation by Government and allied stakeholders should be made a priority if the next divestiture will be a success. Previous governments, dating to the start of the $4^{\text {th }}$ Republic from 1992 till date have not paid much attention to any other mineral besides gold and this has hurt the diamond sector. Lastly, we recommend that govern${ }^{8}$ Most recent amendment to the original Mineral and Mining Law in Ghana was enacted in 2015 as the Mineral and Mining (Amendment) Act, (Act 900). 
ment as a matter of necessity, to lessen the financial burden on the next takeover company, take a stake in the equity of the Akwatia Diamond Mine as the debts accrued over the years have served as a deterrent for investments.

The main limitation of this study is in its inability to access the official government documents and relevant data pertaining to the divestiture of the Akwatia Diamond Mine won by Sapper and Associates and GCDCL. This resulted in the inability to properly determine if there were any drawbacks in the divestiture documentation and procedure, thereby affecting the scope of the study.

This study encourages further studies into the divestiture documentation and procedure of the government of Ghana in the disposal of State-Owned Enterprises (SOEs).

\section{Conflicts of Interest}

The authors declare no conflicts of interest regarding the publication of this paper.

\section{References}

[1] Kaakpema, Y. and Saleem, H.A. (2005) Multiple Scales of Diamond Mining in Akwatia, Ghana: Addressing Environmental and Human Development Impact. Resources Policy, 30, 145-155. https://doi.org/10.1016/j.resourpol.2005.08.001

[2] Akabzaa, T. and Darimani, A. (2001) Impact of Mining Sector Investment in Ghana: A Study of the Tarkwa Mining Region. A Draft Report Prepared for SAPRI.

[3] Songsore, J., Yankson, P.W.K. and Tsikata, G.K. (1994) Mining and the Environment: Towards a Win-Win Strategy. A Study of the Tarkwa-Aboso-Nsuta Mining complex in Ghana, 185.

[4] Kurtishi-Kastrati, S. (2013) The Effects of Foreign Direct Investments for Host Country's Economy. European Journal of Interdisciplinary Studies, 5, 26-38.

[5] Mwilima, N. (2003) Foreign Direct Investment in Africa. Social Observatory Pilot Project. Final Draft Report, 29-45.

[6] Antwi, S., Atta Mills, E., Atta Mills, G. and Zhao X. (2013) Impact of Foreign Direct Investment on Economic Growth: Empirical Evidence from Ghana. International Journal of Academic Research in Accounting, Finance and Management Sciences, 3, 18-25.

[7] Awudi, G.B. (2002) The Role of Foreign Direct Investment (FDI) in the Mining Sector of Ghana and the Environment. Paper Presented at CCNM Global Foreign Direct Investment and the Environment, OECD. Paris, France. http://www.oecd.org/countries/ghana/1819492.pdf

[8] Zhang, K.H. (2005) How Does FDI Affect a Host Country's Export Performance? The Case of China. International Conference of WTO, China and the Asian Economies, 25-26.

[9] Iwamoto, M. and Nabeshima, K. (2012) Can FDI Promote Export Diversification and Sophistication of Host Countries? Dynamic Panel System GMM Analysis. Institute of Developing Economies, Discussion Paper No. 347.

[10] Alfaro, L. (2003) Foreign Direct Investment and Growth: Does the Sector Matter? Working Paper, Harvard Business School, Harvard.

[11] Gu, W., Awokuse, T.O. and Yuan, Y. (2008) The Contribution of Foreign Direct 
Investment to China's Export Performance: Evidence from Disaggregated Sectors. Paper Prepared for Presentation at the American Agricultural Economics Association Annual Meeting. Orlando.

[12] Vernon, R. (1966) International Investment and International Trade in the Product Cycle. Quarterly Journal of Economics, 80, 190-207. https://doi.org/10.2307/1880689

[13] Brainard, S.L. (1993) A Simple Theory of Multinational Corporations and Trade with a Trade-off between Proximity and Concentration. National Bureau of Economic Research, Working Paper Series, No. 4269. https://doi.org/10.3386/w4269

[14] Blonigen, B.A. and Feenstra, R.C. (1997) Protectionist threats and foreign direct investment. In: Feenstra, R.C., Ed., Effects of US Trade Protection and Promotion Policies, University of Chicago Press, Chicago, IL. https://doi.org/10.3386/w5475

[15] Schmitz, A. and Helmberger, P. (1970) Factor Mobility and International Trade: The Case of Complementarity. American Economic Review, 60, 761-767.

[16] Horst, T. (2015) American Multinationals and the US Economy. American Economic Association, 66, 149-154.

[17] Markusen, J.R. (1983) Factor Movements and Commodity Trade as Complements. Journal of International Economics, 14, 341-356. https://doi.org/10.1016/0022-1996(83)90009-0

[18] Ekholm, K., Forslid, R. and Markusen, J.R. (2005) Export-Platform Foreign Direct Investment. National Bureau of Economic Research, Working Paper, No. 9517. Cambridge University Press, Cambridge, MA. https://doi.org/10.2139/ssrn.739213

[19] Mattson, J.W. and Koo, W.W. (2002) U.S. Processed Food Exports and Foreign Direct Investment in the Western Hemisphere. Agribusiness \& Applied Economics. Report 23547, North Dakota State University, Fargo, ND.

[20] Marchant, M.A., Saghaian, S.H. and Vicknera, S.S. (1999) Trade and Foreign Direct Investment Management Strategies for U.S. Processed Food Firms in China. The International Food and Agribusiness Management Review, 2, 131-143. https://doi.org/10.1016/S1096-7508(00)00022-7

[21] Chunlai, C. (1997) Foreign Direct Investment and Trade: An Empirical Investigation of the Evidence from China. Chinese Economy Research Unit Working Paper, No. 97/11. The University of Adelaide, Adelaide.

[22] Somwaru, A. and Bolling, H.C. (1999) U.S. Foreign Direct Investment and Trade: Substitutes or Complements? The Case of The Food Processing Industry, No. 21715, 1999 Annual Meeting, American Agricultural Economics Association, August $8-11$, Nashville, TN.

[23] Guerrieri, P. (1998) Trade Patterns, FDI, and Industrial Restructuring of Central and Eastern Europe. BRIE, Working Paper, No. 124.

[24] Kaminski, B. (1990) Foreign Trade and FDI in Hungary and Slovenia: Different Paths-Different Outcomes. Transition, World Bank.

[25] Goldberg, L. and Klein, M. (1999) International Trade and Factor Mobility: An Empirical Investigation, National Bureau of Economic Research, Working Paper, No 7196. https://doi.org/10.3386/w7196

[26] Olsson, O. (2007) Conflict Diamonds. Journal of Development Economics, 82, 267-286. https://doi.org/10.1016/j.jdeveco.2005.07.004

[27] Hillbom, E. (2012) Botswana: A Development-Oriented Gate-Keeping State. African Affairs, 111, 67-89. https://doi.org/10.1093/afraf/adr070

[28] Kyngdon-McKay, Y. (2014) Review-Diamonds. E-International Relations. June 15 
https://www.eir.info/2014/06/05/review-diamonds/

[29] Insah, B. (2013) Foreign Direct Investment Inflows and Economic Growth in Ghana. International Journal of Economic Practices and Theories, 3.

[30] Frimpong, J.M. and Oteng-Abayie, E.F. (2008) Bivariate Causality Analysis between FDI Inflows and Economic Growth in Ghana. International Research Journal of Finance and Economics, 15, 103-112.

[31] Sackey, F.G., Compah-Keyeke, G. and Nsoah, J. (2012) Foreign Direct Investment and Economic Growth in Ghana. Journal of Economics and Sustainable Development, 3, 120-133.

[32] Carkovic, M.V. and Levine, R.E. (2002) Does Foreign Direct Investment Accelerate Economic Growth? University of Minnesota, Minneapolis, MN. https://doi.org/10.2139/ssrn.314924 http://siteresources.worldbank.org/INTFR/Resources/fdi.pdf

[33] Borensztein, E., Gregorio, J.D. and Lee, J.W. (1998) How Does Foreign Direct Investment Affect Economic Growth? Journal of International Economics, 45, 115-135. https://doi.org/10.1016/S0022-1996(97)00033-0

[34] Blomstrom, M., Lipsey, R.E. and Zejan, M. (1992) What Explains Developing Country Growth? National Bureau of Economic Research, Working Paper Series, 7-13. https://doi.org/10.3386/w4132

[35] Asiedu, E. (2006) Foreign Direct Investment in Africa: The Role of Natural Resources, Market Size, Government Policy, Institutions, and Political Instability. The World Economy, 29, 63-77. https://doi.org/10.1111/j.1467-9701.2006.00758.x

[36] Campos, N.F. and Kinoshita, Y. (2008) Foreign Direct Investment and Structural Reforms: Evidence from Eastern Europe and Latin America. IMF Working Papers. IMF, Washington DC. https://doi.org/10.5089/9781451868883.001 https://www.imf.org/external/pubs/ft/wp/2008/wp0826.pdf

[37] Cockcroft, L. and Riddell, R.C. (1991) Foreign Direct Investment in Sub-Saharan Africa. World Bank Working Paper, International Economics Department, Washington DC.

[38] Itagaki, T. (1981) The Theory of the Multinational Firm under Exchange Rate Uncertainty. Canadian Journal of Economics, 14, 276-297. https://doi.org/10.2307/134798

[39] Aliber, R. (1970) A Theory of Foreign Direct Investment. In: Kindleberger, C.P., Ed., The International Corporation: A Symposium, 5th Edition, MIT Press, Cambridge, MA, 17-34.

[40] Kyereboah-Coleman, A. and Agyire-Tettey, K.F. (2008) Effect of Exchange-Rate Volatility on Foreign Direct Investment in Sub-Saharan Africa: The Case of Ghana. Journal of Risk Finance, 9, 52-70. https://doi.org/10.1108/15265940810842410

[41] Asiedu, E. (2002) On the Determinants of Foreign Direct Investment to Developing Countries: Is Africa Different? World Development, 30, 107-119. https://doi.org/10.1016/S0305-750X(01)00100-0

[42] Mash, R. (1998) The Investment Response to Temporary Commodity Price Shocks. Centre for the Study of African Economies, Working Paper Series, No. 14.

[43] Hailu, Z. (2010) Demand Side Factors Affecting the Inflow of Foreign Direct Investment to African Countries: Does Capital Market Matter? International Journal of Business and Management, 5, 104-116. https://doi.org/10.5539/ijbm.v5n5p104

[44] Twimukye, E. (2006) An Econometric Analysis of Determinants of Foreign Direct Investment: A Panel Data Study for Africa. 93. 
[45] Fontagne, L. and Pasteels, J. (2003) TradeSim (Second Version), a Gravity Model for the Calculation of Trade Potentials for Developing Countries and Economies in Transition. International Trade Center Working Paper, 10-16.

[46] Frankel, J.A. (1997) Regional Trading Blocs in the World Economic System. Peterson Institute Press, Washington DC.

[47] Frankel, J.A. and Romer, D.H. (1999) Does Trade Cause Growth? American Economic Review, 89, 379-399. https://doi.org/10.1257/aer.89.3.379

[48] Addai, K.N. and Baiden, W.B. (2014) Effect of Small Scale Mining on the Environment of Tarkwa-Nsuaem Municipality of Ghana. Journal of Environment and Earth Science, 4, 73-81.

[49] Amponsah-Tawiah, K. and Dartey-Baah, K. (2011) The Mining Industry in Ghana: A Blessing or a Curse. International Journal of Business and Social Science, 2, 62-69. 